\title{
Governance structure, mechanisms and methods for managing collaborative eBusiness projects
}

\author{
Julie Cameron \\ University of New South Wales, Sydney, Australia, jcameron@iprimus.com.au
}

\begin{abstract}
Increasingly ebusiness projects are undertaken by collaborations. Many collaborative ebusiness projects fail to achieve their stated objectives due partly to inadequate project management. Additional management functions result from the lack of central authority and the characteristics of the three levels involved in these projects: the participating organizations that voluntarily collaborate (a form of virtual organization) to achieve agreed ebusiness objectives; the project teams (normally operating as "virtual" teams); and representatives from participating organizations. Because management functions change during the three stages of the "Collaborative Project Management Lifecycle" ${ }^{\circledR}$, it is proposed that the governance structure, mechanisms and methods adopted also need to change to effectively coordinate participating organizations and manage project activities. This proposal is evaluated using case studies of five Australian ebusiness collaborative projects. The paper contributes to practice by comparing various governance structures, mechanisms and methods and discussing the implications from a management perspective. The results are used to suggest governance structures, mechanisms and methods appropriate to key attributes of collaborative ebusiness projects. The paper synthesizes and builds on existing research related to collaborations, project management, virtual organizations and virtual teams, and then applies these findings to a real world environment.
\end{abstract}

Keywords: collaboration; project management; virtual organization, virtual team; lifecycle

\section{Introduction}

Now that the benefits promised by ICT (Information and Communication Technology) are achievable, are understood by business, and accepted by users and consumers, ebusiness ${ }^{1}$ has become ubiquitous in the "developed" world. As the disadvantages and costs of decentralised processing decrease, a growing number of geographically dispersed, independent organisations are collaborating to produce and supply products and services (JardimGoncalves, Cha et al., 2003). When the ICT systems of these organizations are integrated, and processing is automated, business operations and practice are transformed (Clarke, 1994a; Hirst and Robertson, 1997). Consequently, ebusiness projects are increasingly initiated as voluntary collaborations of independent organizations that form a trading, value or

\footnotetext{
${ }^{1}$ The United States Census Bureau (October 2000) defines "ebusiness" as "any process that a business organization conducts over computer-mediated network channels." To reflect current and emerging developments this definition is expanded to include "all business activities utilising all forms of ICT and digital technology" (e.g. automated voice response; video streaming). eBusiness includes collaborative commerce which uses ICT to enable collaborative relationships along a value chain and knowledge flows among distributed participants engaged in various joint activities.
}

transaction chain. These projects are known as "collaborative ebusiness projects".

A collaborative ebusiness project is "a project undertaken by a group of independent organizations, with no single authority, that have made a commitment (whether formally or informally) to work together (with or without equity sharing) to develop and implement an ebusiness initiative in order to achieve mutually agreed outcomes" ${ }^{2 "}$ (Cameron, 2005). Currently this implies use of the internet or some other electronic network. From a management perspective, ebusiness collaborative projects combine the challenges of coordinating voluntary collaborations of independent organizations with the management complexity associated with ebusiness projects involving extensive trading chains. Collaboration is a process that goes on within a collaborative ebusiness project. Although many of the characteristics of ebusiness collaborative projects mirror those of business alliances, they differ because of their temporal nature, lack of separate legal identity and the project management and technical contexts. Participating organizations collaborate as a form of virtual organization to achieve technical objectives within specified timeframes. Completion of project activities depends on representatives from numerous organizations

\footnotetext{
2 This definition is based on that used in previous research (Cameron \& Clarke, 1996)
} 
that form virtual ${ }^{3}$ teams. The lack of a single authority imposes specific management challenges not associated with other types of project.

Collaborative ebusiness projects frequently fail to achieve their stated objectives. Comparative, reliable statistics about outcomes for these projects are not available. "Failed" projects are often not reported. Industry sources ${ }^{4}$ estimate that about $80 \%$ of ebusiness collaborative projects fail to be implemented by enough partners to provide the critical mass of transactions required to make ebusiness financially viable. This estimate is credible considering that $40-70 \%$ of all forms of joint ventures and alliances fail (Cameron, 2002; McGrath and More, 2002). Poor outcomes can result from organizations leaving the collaboration, as well as from failure to complete the project or to implement the solution (Cameron, 2002). Even when ebusiness initiatives are implemented, most projects have a very slow rate of take-up throughout the trading chain (Tradegate, 2003). Some projects succeed "in the pilot sense but [have difficulty] in building up from there" (McGrath and More, 2002) (p. 66). Project outcomes need to be improved.

Inadequate project management processes and lack of essential project management skills are reported as one cause of poor outcomes for collaborative ebusiness projects (Fear and Barnett, 2003; NOIE, 2002; OVUM, 2003). The nature of the inter-relationships is complex. "Across a broad range of [collaborative ebusiness] projects, many project participants have come to realise that managing people, relationships, and business processes is harder than managing technology" (McGrath and More, 2002) (p. 4). "Management of a short term co-operative effort" is also a success factor for virtual organizations (Crowston and Scozzi, 2002) (p. 4). "Unfortunately, developments in the design and management of complex IT systems do not seem to have kept pace with the potential of hardware, or with human ambition!" (Royal Academy of Engineering \& British Computer Society, 2004) (p. 11).

Australian practitioners reported that traditional ICT project management methodologies are often not used for collaborative ebusiness projects. Some projects are "managed" on an "ad hoc" basis. Only 31\% of the 67 ITOL funded projects studied had established clear written agreements delineating roles and responsibility, and 17\%

\footnotetext{
3 "Team virtuality is defined as a multi-dimensional team characteristic that differentiates virtual from conventional teams on four dimensions: temporariness, physical distance, cross boundary distribution, and communication means." (Grevins, 2002) (page 1)

${ }^{4}$ Sources: Unpublished research from a multi-national ICT vendor and personal communication with Australian ICT industry practitioners interviewed by the researcher in 2004 .
}

did not document processes even though they were required to report to government (McGrath and More, 2002). Methodologies are not used because they are considered inappropriate for use by multiple organizations "where interpersonal and inter-organizational relationships, trust and communication replace formal power and authority structures" (Cameron and Clarke, 1996). Project plans cannot be imposed on the participating organizations or virtual teams. Management limitations resulting from lack of formal power and authority are exacerbated by practical concerns about the rigour and demands imposed by some methodologies. Assumptions incorporated into the processes (e.g. numerous "sign offs" or management approvals for "deliverables") are not valid for collaborative projects involving a large number of independent organizations. The amount and type of documentation required is not practical for use by all participating organizations (e.g. small business). The governance structure and mechanisms adopted affect the "controlling" methods available to the project manager (Project Management Institute, 2000).

This paper reports on research that is part of a larger project aimed at improving collaborative ebusiness project outcomes. Written from the perspective of a project management practitioner, the author:

1. Summarizes the management context identified in literature and previous research and proposes that because management functions change during the "Collaborative Project Management Lifecycle" $\odot \oplus$, the governance structure, mechanisms (e.g. the way commitment is formalized) and methods used also need to change to effectively coordinate the participating organizations and manage project activities (Section 2).

2. Describes the method used for this research and acknowledges its limitations (Section 3).

3. Describes and compares the governance structures, mechanisms and methods used in five Australian collaborative ebusiness projects to coordinate the participating organizations and manage project activities during the three stages of the lifecycle and evaluates the proposition (Section 4).

4. Discusses the implications of the governance structures, mechanisms and methods from a management perspective (Section 5).

5. Suggests governance structures, mechanisms and methods appropriate to key attributes of collaborative ebusiness projects and concludes with summary of the paper's contributions to practice and research (Section 6).

The scope of this paper concentrates on Australian collaborative ebusiness projects that received some government funding. The importance of the skills, personality traits, leadership behaviour and management 
style of the project manager (McGrath and More, 2002) is acknowledged but is not addressed in this paper which focuses on governance structures, mechanisms and methods.

\section{The management context}

There is a significant body of literature about project management and factors that affect project outcome. There is also a large amount of research related to business alliances and joint ventures (ie collaborations of organizations). However, most research assumes projects are undertaken within a single organization and collaborations occur within a single authority and/or are defined by contractual terms and conditions. More recently researchers have focussed on aspects of managing virtual organizations (Grabowski and Roberts, 1999; Katzy, 1998; Koch, Moslein et al., 2004; Speier and Harvey, 1998) and virtual teams (Anjum, Zafar et al., 2006; Bain, Mann et al., 2001; Lu, Watson-Manheim et al., 2006; Piccoli and Powell, 2004). The management context of this author's current research is grounded in, and supported by, concepts related to both virtual organizations and virtual teams. The concepts embodied within the collaborative project are included in a future hypothetical organization, founded on a "collaborative entrepreneurship model" based on "a) an entrepreneurial strategy that creates economic value through continuous innovation, b) pursued by a network of self-managing [virtual teams of] member and affiliate firms and c) operated by the essential capability of intra- and inter-firm collaboration" (Miles, Miles et al., 2005) (p. 9). Although they are not selfmanaging, collaborative ebusiness projects encompass the other concepts of collaborative entrepreneurship. Because this paper is aimed particularly at practitioners seeking to understand the complexities of managing collaborative ebusiness projects, it excludes the analysis of literature and theory that informed this research.

"The appropriateness of the level [of analysis adopted for research] depends on the constituency being used, the domain being focused on, the purpose of the evaluation, and so on" (Seddon, Staples et al., 1999). Information systems, InterOrganizational Systems (IOS) and ebusiness researchers mainly focus on the levels of organizational network, industry and society (Reimers, Johnson et al., 2004). Most IOS research, including frameworks purporting to support project management and explain IOS project outcome (McNichols and Brennan, 2004), tends to concentrate on the organizational level of analysis. Project management research, including studies into effective management of virtual teams, considers the levels of teams and individuals (Bain, Mann et al., 2001; Grevins, 2002; West, 2002). Case studies of seven Australian collaborative ebusiness projects ${ }^{5}$ were examined to ascertain the levels of analysis that needed to be included when considering industry "best practice" for project management. After comparing research and practice the author concluded that ebusiness collaborative project outcome is determined by activities and processes undertaken separately and together by the following three levels and their interactions (Cameron, 2005):

1. Participating organizations that affect, and in turn are affected by the collaboration.

2. Teams of representatives from participating organizations (including the governance body) established to undertake project activities that are normally virtual in nature.

3. Representatives as they relate to the collaboration and to the organizations by which they were appointed.

The "Framework for the Study of Interorganizational Collaboration" (Hartono and Holsapple, 2004) developed from definitions of collaboration as a foundation for collaborative commerce research and practice, supports the author's findings. The inclusion of three levels of participating organizations, teams and representatives both reflects and extends the levels of analysis examined in research into collaborations and project management. "The appropriate methodology depends on the project and the underlying concepts and techniques associated with the methods." (p. 263) (Olle, Hagelstein et al., 1988) The key attributes of collaborative ebusiness projects that affect the management context are the:

1. Three levels to manage: participating organizations, virtual teams and representatives together with their inter-relationships and interactions (Cameron, 2005).

2. Voluntary nature of collaboration that means project management lacks formal power and authority.

3. Virtuality, which comprises four dimensions: temporariness, geographical spread, cross boundary distribution, and communication media (Grevins, 2002; Leenders, van Engelen et al., 2003; Lu, Watson-Manheim et al., 2006). Project management must coordinate the activities representatives from geographically dispersed, diverse organizations.

4. Level of control required due to perceived risk arising from the technology and/or from relationships. (Allen, Colligan et al., 2000; Gallivan and Depledge, 2003; Grabowski and Roberts, 1999) Tension may occur among

\footnotetext{
${ }^{5}$ Four case studies were associated with international trade and transport (Clarke, 1994a, 1994b; Hirst \& Robertson, 1997; Tradegate, 1994-97, 2003; Tradegate-ECA, 1997-2002); one each from the book trade (Cameron \& Clarke, 1996), the food export industry (Wilkins, Swatman et al., 2001), and funds management (mFundEC, 2001-2003).
} 
some organizations because they are competitors but need to co-operate - a phenomenon known as "coopertition" (Loebbecke, Fenema et al., 1998; Rayport and Jaworski, 2001). Each organization needs to be assured that collaborating will not jeopardize its business interests and will seek to minimize risk.

5. Three stage lifecycle required by collaborative ebusiness projects (Cameron, 2006).

6. Number of participating organizations and stakeholders affected by the span of the project (e.g. a short specified trading chain or from several industries).

7. Scope and reach of the technology and the related project objective (e.g. standards development and industry implementation compared to electronic exchange of documents among trusted partners).

Lack of formal power and authority complicates management at both the collaboration and the project layers. This complexity is exacerbated by increases in virtuality, number of participating organizations and the scope and reach of the objective and related technology.

The characteristics of the relationships among participating organizations which affect the management of all forms of collaboration not established as separate legal entities (Gray and Wood, 1991a, 1991b; Hardy, Lawrence et al., 2005) include:

- Interactions and inter-relationships among independent organizations.

- Volunteer organizations, which if dissatisfied, may become inactive or leave.

- Benefits that must be dispersed "fairly" among all participating organizations.

Project management, defined as "the application of knowledge, skills, tools and techniques to project activities to meet project requirements ...is accomplished though the use of processes" [that include] "controlling" (p. 6) (Project Management Institute, 2000). Management "control" of collaborative ebusiness project activities is affected by lack of authority and virtuality which means (Cameron and Clarke, 1996):

- Decisions cannot be enforced on participating organizations.

- Roles and responsibilities are more complex than those within a single organization and/or authority.

- Resources are not centrally controlled and participating organizations choose what they provide, and when they provide it.

- Resources, skills, expertise vary and fluctuate.

- Organizational cultures and management practices differ so that internal processes and procedures (e.g. ICT project management methods) vary.
eBusiness projects differ from other ICT projects because of their scope and reach. The ICT used for ebusiness is an addon to existing technology (Lyytinen and Damsgaard, 2001). Organizations are required to interface their internal ICT systems and interoperate with partners via communications infrastructures. The scope of ebusiness includes integrating diverse data sets and business processes across disparate organizations. eBusiness cannot be implemented without cooperative effort. Although the reach of all ebusiness projects is "boundary spanning" (Emmelhainz, 1990; Kinni, 1994) many ebusiness projects are undertaken within a single organization (e.g. business to consumer implementations involving web-based transaction processing). Some are based on compliance and not collaboration. Organizations may participate because of regulatory and buyer-supplier relationships. eBusiness implementation may be regulated by a government authority as a pre-condition for undertaking a required transaction (e.g. customs clearance).

A lifecycle $e^{6}$ provides a framework for project management activities and processes. It therefore needs to be appropriate to the management context. Lifecycles for collaborations (Hartono and Holsapple, 2004; Svirskas and Roberts, 2003), virtual organizations (Katzy, 1998), collaboratively engineered products (Jardim-Goncalves, Cha et al., 2003) and ICT lifecycles were compared with "best practice" ascertained by the author from case studies of collaborative ebusiness projects. None of the existing published lifecycles combined phases essential for collaboration with those required by ebusiness projects. Based on findings from practice and research a three stage "Collaborative Project Management Lifecycle"®®7 (Figure 2) was developed in 2003 (Cameron, 2005) and validated in 2005 (Cameron, 2006). A Collaboration Formation and Maintenance Stage was added before the planning phases of a "traditional" ICT development lifecycle if a "Waterfall Method" is used. A Take-up and Implementation Stage, during which ebusiness is adopted by the trading and/or value chain and industries, was added after the development phases familiar to ebusiness practitioners. The purpose of "Collaborative Project Management Lifecycle ${ }^{\left({ }^{\circledR}\right.}$ is to explain the

\footnotetext{
${ }^{6} \mathrm{~A}$ lifecycle is "a collection of generally sequential project phases" [comprising "] a collection of logically related project activities that usually culminate in the completion of a major deliverable"... "whose name and number are determined by the control needs of the organization(s) involved in the project." (p. 55) (Project Management Institute, 2000).

${ }^{7}$ Copyright in the "Collaborative Project Management Lifecycle" ${ }^{(\circledast)}$ (also known as the "Collaborative eBusiness Project Lifecycle" ${ }^{(®)}$ ) is owned by cPROM, a division of Info.T.EC Solutions Pty Ltd. It is reproduced with the permission of the owner.
} 
extra management functions, provide a framework for collaborative project management methods, and support the management of the collaboration and the project.

Figures 1 and 2 show key differences in the management context of ebusiness projects due to collaboration. To facilitate comparison, each figure shows a typical management structure and lifecycle.

Figure 1 illustrates the management context of an ebusiness project established within a single organization or authority. Significantly, project management has the authority inherent in their organizational role (legitimate power), to direct staff and mandate completion of activities to specification within timeframes. The ebusiness initiative development lifecycle does not require the management functions and activities association with collaboration.

A comparison of Figure 2 with Figure 1 shows the management complexity arising from the three levels that need to be managed. As shown in Figure 2, a central governance body coordinates organizations participating in the collaboration. Its membership includes senior

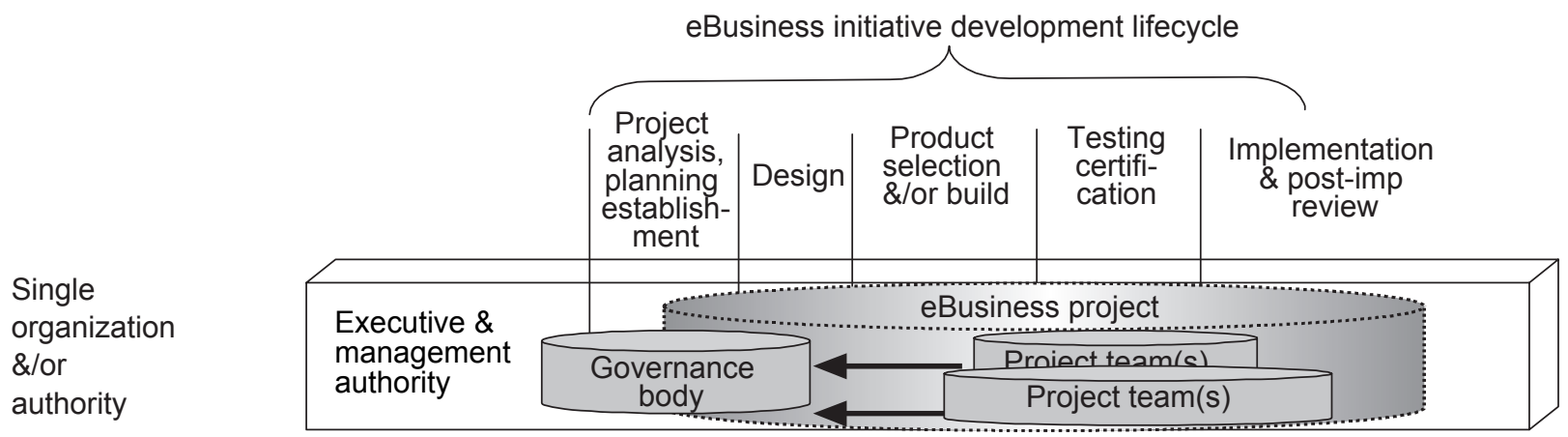

Figure 1. eBusiness within a single authority.

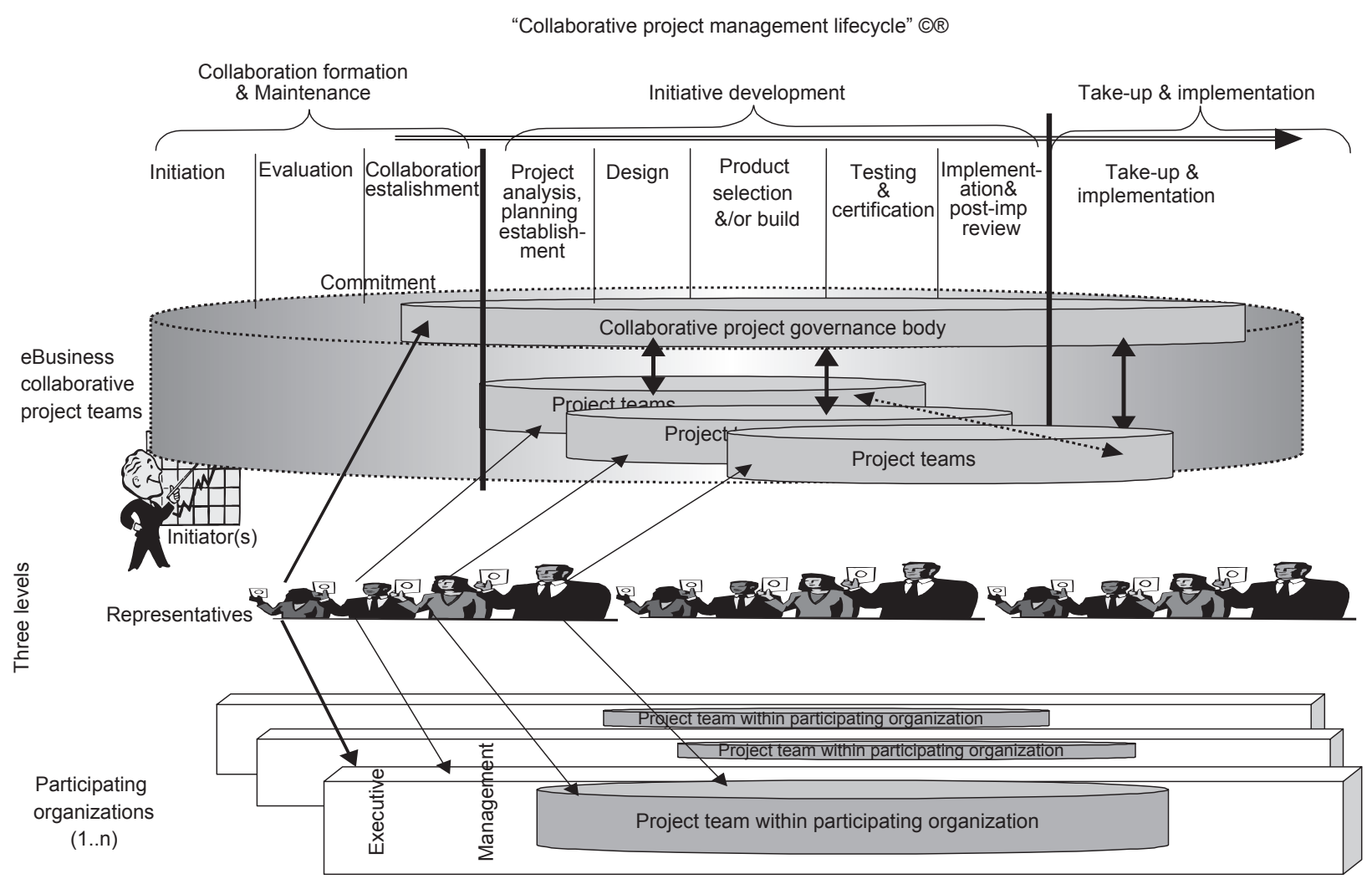

Figure 2. eBusiness collaborative projects. 
management from some or all of the participating organizations and often from other key stakeholders. Project teams (that are normally virtual) undertake activities needed to complete the objectives set by the governance body. The representative level (shown in the centre of Figure 2) comprises individuals appointed to teams by participating organizations. Arrows reaching from the representatives to their organization and to the collaborative ebusiness project indicate their joint responsibilities. Representatives remain accountable to their own organization and are rarely allocated to the project full-time.

The Collaboration Formation Stage (to the top left of Figure 2) of the lifecycle begins with the Initiation Phase. The "initiator" or "champion" is often an individual within a key innovative organization (Rogers, 1995) supported by an industry association. Champions help to recruit participants during the Evaluation Phase. During the Collaboration Establishment Phase, a governance body is established. Collaboration Maintenance adds management functions that continue throughout the lifecycle. Although phases in the Initiative Development Stage depend on the technology and develop method(s) used, they reflect those of similar ebusiness projects. Activities may take longer to complete because of the number of organizations involved and lack of project management control over resources and schedules. This stage includes preliminary implementation, often as a "proof of concept" by early adopters among participating organizations. The Take-up and Implementation Stage is frequently lengthy.

\section{Proposal}

As shown by the "Collaborative Project Management Lifecycle" ${ }^{\circledR}$, management functions change depending on what is being controlled (collaboration or project) and the activities required to achieve the objectives. It is therefore proposed that because management functions change during the "Collaborative Project Management Lifecycle" ${ }^{\prime \oplus}$, the governance structure, mechanisms and methods used also need to change to effectively coordinate the participating organizations and manage project activities.

\section{Research method}

Case study research was justified by the complexity of the subject within its real world environment, the three levels of analysis and the richness of the collaborative ebusiness project context (Yin, 1994). A mixed method qualitative research design (Bloor, 1997; Creswell, 2003) was underpinned by case study research design (pp38-89) (Yin, 1994). Purposive sampling (Silverman, 2000) was used to select projects as case studies that were sufficiently diverse to enable issues of central importance to this research, including the affect of the attributes of collaborative ebusiness projects to be examined. Drawn from a range of industry sectors, the five projects selected were "information rich" and more than one source of information was available about each. These five projects differed from the seven case studies used to establish the characteristics of collaborative ebusiness project and to develop the "Collaborative Project Management Lifecycle" ${ }^{\circledR \circledast}$. The five case studies were:

- "Supply18", "Supply2" and "Supply3" projects that aimed to develop industry standards and demonstrate the feasibility of data exchange via the internet on an "any-to-any", "any-to-many" transactional network basis best illustrated by the flexibility of the fax machine. Each project involved a product supply chain in a different industry.

- "Trans" project that aimed to develop and implement industry electronic data and messaging standards and protocols to enable automated transaction processing.

- "DocEx" Project that aimed to send complex electronic documentation (edocuments) from one organization via a warehouse, for processing within other organizations.

Table 1 lists the projects in the order in which they were initiated and their attributes. The ten-year period enabled any changes in management complexity resulting from evolution in ICT to be identified. The number of participating organizations reflected the size of trading, value and/or transaction chain, and industry span. When participating organizations came from more than one industry or sector it was more difficult to ensure benefits and risks were fairly dispersed. The geographical spread indicated project impact and "virtuality". The level of competition among participating organizations affected the nature of relationships. The objectives, ICT utilised and number of sub-projects determined the technical scope and reach.

Figure 3 compares the five projects on the basis of the number of participating organizations (represented by the size of the oval), the time taken to complete each Stage and their reported outcome.

Each project was undertaken in two stages. A staged approach is typical for ebusiness collaborative projects. Stage 1 of all projects comprised Collaboration Formation and Initiative Development including standards, protocol and production testing. The time taken to complete Stage 1 ranged from 4 years (Supply1) to 9 months (DocEx). Stage 2 of the Trans, Supply1 and Supply3 projects aimed to achieve industry implementation and take up throughout

\footnotetext{
${ }^{8}$ Each project was given a pseudonym in order to maintain confidentiality
} 
Table 1. Diversity of case studies.

\begin{tabular}{|c|c|c|c|c|c|}
\hline Project & Time of initiation & No. orgs & Geog spread & $\begin{array}{l}\text { Nature of relations \& } \\
\text { span }\end{array}$ & $\begin{array}{l}\text { Scope \& reach of technology \& project } \\
\text { objectives }\end{array}$ \\
\hline Supply1 & Mid 1990s & 90 & Australia -wide & $\begin{array}{l}\text { Competitors. } \\
\text { Inter-industry trading } \\
\& \text { value chain }\end{array}$ & $\begin{array}{l}\text { Standards development } \& \text { internet based } \\
\text { messaging and data exchange for multiple } \\
\text { industry sectors ( } 5 \text { sub-projects) }\end{array}$ \\
\hline Trans & 2 years after Supply1 & 35 & Four States & $\begin{array}{l}\text { Competitors. } \\
\text { Intra-industry } \\
\text { transaction chain }\end{array}$ & $\begin{array}{l}\text { Standards \& XML message development for } \\
\text { data exchange \& automated processing of } \\
\text { industry transactions (8 sub-projects) }\end{array}$ \\
\hline Supply2 & 5 years after Supply1 & 39 & Southern States & $\begin{array}{l}\text { Competitors. } \\
\text { Industry trading chain }\end{array}$ & $\begin{array}{l}\text { Standards development \& electronic message } \\
\text { exchange ( } 1 \text { project) }\end{array}$ \\
\hline Supply3 & 6 years after Supply1 & 14 & Southern States & $\begin{array}{l}\text { Competitors. } \\
\text { Sector trading chain }\end{array}$ & $\begin{array}{l}\text { Standards development, repository \& } \\
\text { electronic message exchange ( } 1 \text { project) }\end{array}$ \\
\hline DocEx & 6 years after Supply1 & 8 & One City \& State & $\begin{array}{l}\text { Government orgs. } \\
\text { Transaction chain }\end{array}$ & $\begin{array}{l}\text { Electronic documentation exchange, ware- } \\
\text { housing and processing by users ( } 1 \text { project) }\end{array}$ \\
\hline
\end{tabular}

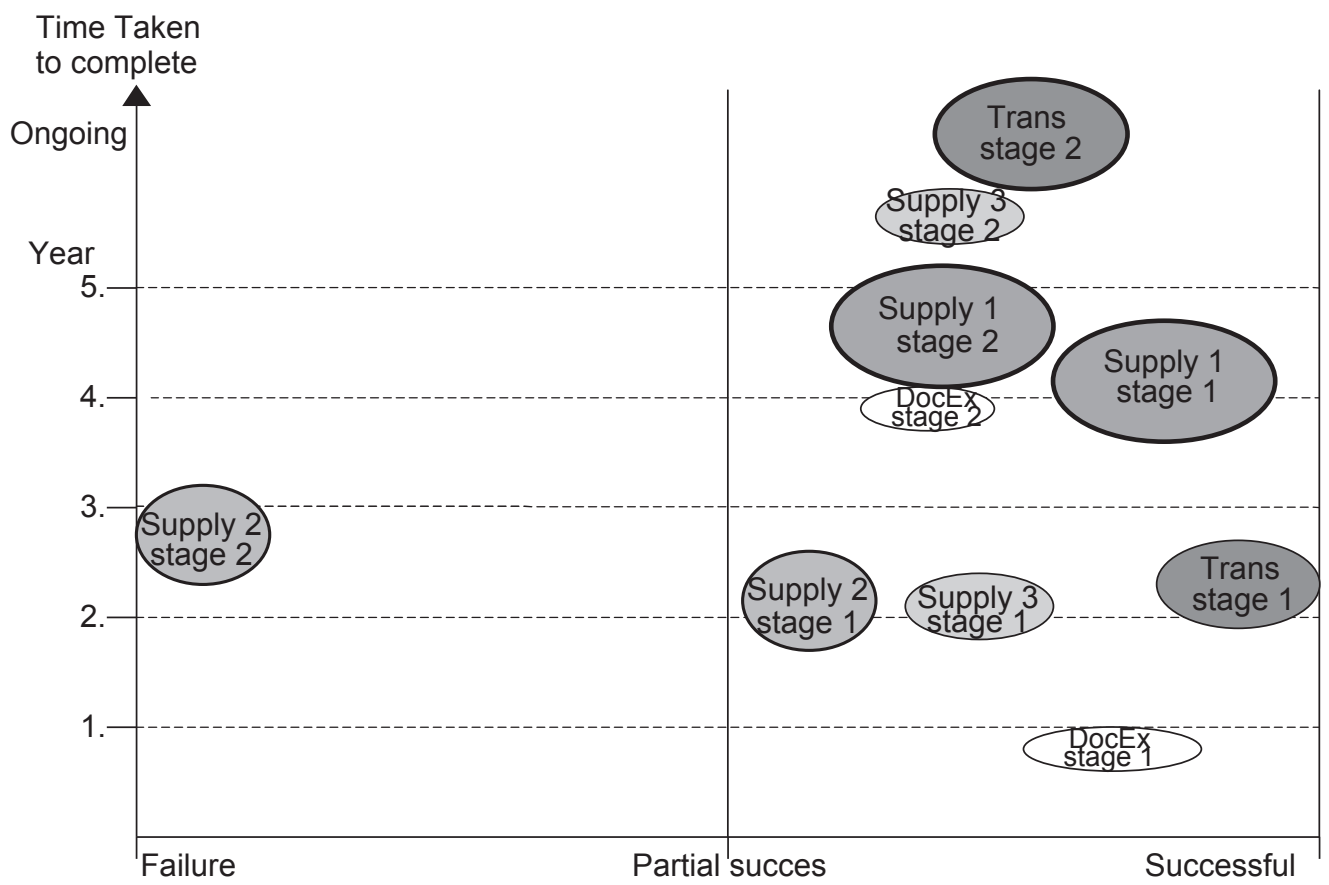

Reported outcome

Figure 3. Reported outcomes of project stages.

the trading chain. Supply1, the largest project, which involved 90 participating organizations from throughout Australia over a period of about 5 years, was successful in completing the demonstration projects. Supply 2 ended at the beginning of Stage 2 when government funding ceased and industry, although happy to share costs with government, failed to be the sole provider of additional funds. DocEx was a pilot that aimed to test feasibility of edocuments, identify issues, establish a collaborative working relationship and test benefits. Stage 1 implemented and tested the feasibility of the ICT solution, and assessed user acceptance of edocuments. Stage 2 extended user evaluation and benefit testing. The Trans, Supply3 and DocEx projects were ongoing at the time of research.

Multiple sources of evidence supported the development of converging lines of inquiry (a process of triangulation) 
(Bloor, 1997). Data from three sources was analysed separately: project documentation, interview responses, and secondary sources including case studies and reports published by other researchers. Yin's "three principles of data collection" were used to improve the validity of the research (Yin, 1994). A case study database and archive was constructed. A chain of evidence was maintained to link the information from different sources. Eight practitioners involved in the management team of the projects were interviewed. The author conducted all interviews and each took approximately one hour. The questionnaire instrument comprised a mix of structured and semi-structured questions. All but one of the interviews was recorded (with the respondent's permission), transcribed and all were referred back to the respondent for confirmation. All responses referring to management functions, structure, mechanism and methods were coded manually by level of analysis and stage of the lifecycle.

Project reports and newsletters were used to identify and describe the structure mechanisms and methods used for each stage of the lifecycle (Section 4). The accuracy of the descriptions was confirmed (where possible) from more than one source. The evaluation of the structure, mechanisms and methods adopted by each project (summarised in Section 5) is based on interview data, supplemented by project documentation.

\section{Limitations of this research}

The author acknowledges that this research is limited by the small number of projects included in the sample of case studies. All projects were undertaken within Australia and all received some government funding. To mitigate the impact of the small interview sample, the researcher compared the interview data with project documentation and secondary sources. Only one practitioner was interviewed for the Supply2 and Supply3 projects, but because structure, mechanisms and methods adopted are documented in secondary sources, other researchers can verify the descriptions.

This research examined the governance structure, mechanisms and methods at the collaboration and project management layers. It did not include other aspects of management known to affect project outcome. Representatives who were not members of the project management teams were not interviewed. Therefore, assessment of the implications and effectiveness of the structure, mechanism and methods depended the "perceptions" of the project management team. Although all interpretation and analysis is prone to researcher bias, it is acknowledged that because the author is a collaborative ebusiness project management practitioner as well as researcher, the risk of bias is greater particularly when evaluating the relative effectiveness of mechanisms and methods.

\section{Governance structure, mechanism and method}

The governance structures, mechanisms and methods adopted at the three stages of the "Collaborative Project Management Lifecycle ${ }^{\prime \odot \circledast}{ }^{\circledR}$ by each of the projects are described (and summarized in Table 2) to ascertain variations among projects.

\section{Structure, mechanism and method during collaboration formation}

During the Initiative and Evaluation Phases of the lifecycle, no collaboration governance structures were established for any of the five projects until there was sufficient committed support for the project.

Supply1 was initiated by government as an "exploratory" project because of concern about industry costs and interest in the internet as a solution for ecommerce. A government research group presented the advantages of the internet to industry and from these meetings a "champion" emerged. After discussion with other government organizations and "standards" bodies, the champion interviewed chief executive officers within the industry to ascertain support. The interviews provided the method and opportunity for formal consultation. When there was sufficient support, "teaming agreements" were signed as the mechanism for expressing commitment to collaboration. Government funding (about $60 \%$ of total funds) was sought and received. The remaining funds came from industry sponsors and participating organizations. The governance structure for the collaboration was a "Council" established to agree objectives and provide policy and direction to the project. The council met three to four times a year. Because of the importance and size of the sector affected, a Government Minister chaired the Supply1 Council during the first 18 months of project to raise the profile and encourage industry participation. Members included representatives from government departments, industry associations and standards bodies.

Supply 2 and Supply3 were initiated when the Project Director, as "champion", advocated the benefits of ebusiness to suppliers and manufacturers within two separate industries. Consultative methods were used to gain support. Organizations confirmed their commitment to provide resources to the project by written agreement (the mechanism required as a precondition for applying for government funding). Some government funding was provided to both projects. A Board was established as the 
governance structure to direct policy and set direction for Supply2 and a project Steering Committee of five members was formed. A Steering Committee was established for Supply3.

Trans was initiated when "champions" from industry gained the support of relevant industry associations or standards bodies. A "consortium" was formed using similar methods to Supply2 and Supply3. A letter from organizations, which included a commitment of funds, was used as the collaboration mechanism. Some government funding was received but most of the funds were contributed by participating organizations. Additional funding from industry was required annually so that organizations reconfirmed their commitment each year. The initial governance structure comprised a Council, which was chaired at its monthly meetings by the "lead" industry association. Membership comprised three industry associations, a government regulator and key contributing organizations considered as "industry leaders". Once the collaboration was established, a "champion" was appointed as a part time Program Director. The Council contracted an independent consultancy company to provide a full-time Program Manager who reported to the Program Director. Formal presentations and meetings with key individuals and organizations in the value chain were used to increase support. Council members held a Planning Workshop to assess the benefits expected from the project and refine objectives.

DocEx involved only government organizations. A strategic consultant was engaged to ascertain the feasibility of a pilot project to exchange and process electronic documentation. Government guidelines for organizations collaborating in an activity were used as the method for consultation. These guidelines were essentially checklists to ensure all key stakeholders were consulted and agreed with the proposal. A Business Case, which included objectives and expected benefits for the sector, was used as the commitment mechanism. Once it was "signed-off" (i.e. approved by the participating organizations) the Business Case was referred to a government funding body for consideration. Commitment was reconfirmed (during the budget cycle) when subsequent Business Cases requesting ongoing funding were "signed-off". No formal governance structure was established until funding was approved. A project Steering Committee comprising management representatives from all organizations was established. An executive from "Lead" organization was appointed as chairman and Project Director. The head of the key user organization was the Sponsor. Contracts were established with a Quality Manager and the "Lead" consultancy for the provision of project management services. The Lead Consultancy contracted the Project Manager.

\section{Structure, mechanism and method during initiative development}

Project structure was finalised and virtual project teams were established during the Project Planning Phase of the Initiative Development Stage of the lifecycle. Structures varied among projects as shown in the diagrams that follow.

The written objective for Supply1 was to agree industry standards (including product numbering), establish five demonstration projects (sub-projects shown to the left of Figure 4), and to raise awareness of the technology and the possibility for increased efficiency and changing practices. The governance structure for Stage 1 of Supply1 (shown in Figure 4) was multi-layered to allow consultation among numerous stakeholders. The Steering Committee, which reported to the Council, met 6 times a year. It managed budget allocations and provided guidance to the Project Director. The Project Director was supported by a secretariat located within the funding organization. Activities associated with the five "Demonstration" projects were undertaken by Working Groups, comprising representatives from throughout Australia who "met" at least monthly (using teleconferencing). They were responsible to the Steering Committee. The large number of advisory groups associated with the project structure was designed to ensure the numerous participating organizations and stakeholders were included in the consultation processes.

The Project Director did not use a project management methodology but projects were coordinated via meetings of the Council, Steering Committee and Working Groups. Minutes and notes of meetings were the main means of reporting and monitoring activities. It is not known if the Project Managers of the five demonstration projects used a methodology to manage development other than to ensure that all stakeholders received every document and 'news' item so that no member could ever claim that they were 'not told'.

As shown in Figure 5, the Supply2 structure comprised a Board and Steering Committee to manage the project with similar accountabilities to those for Supply1. Working Groups were established as required. A Project Director was appointed as facilitator and Board chairman. A project management methodology was not used. The project was coordinated via meetings and weekly reports emailed to sponsors (Interview 2004). The participating organizations agreed a single numbering system for their products. They went to tender for a demonstration ebusiness gateway. A hub supplier was selected but implementation did not proceed. 


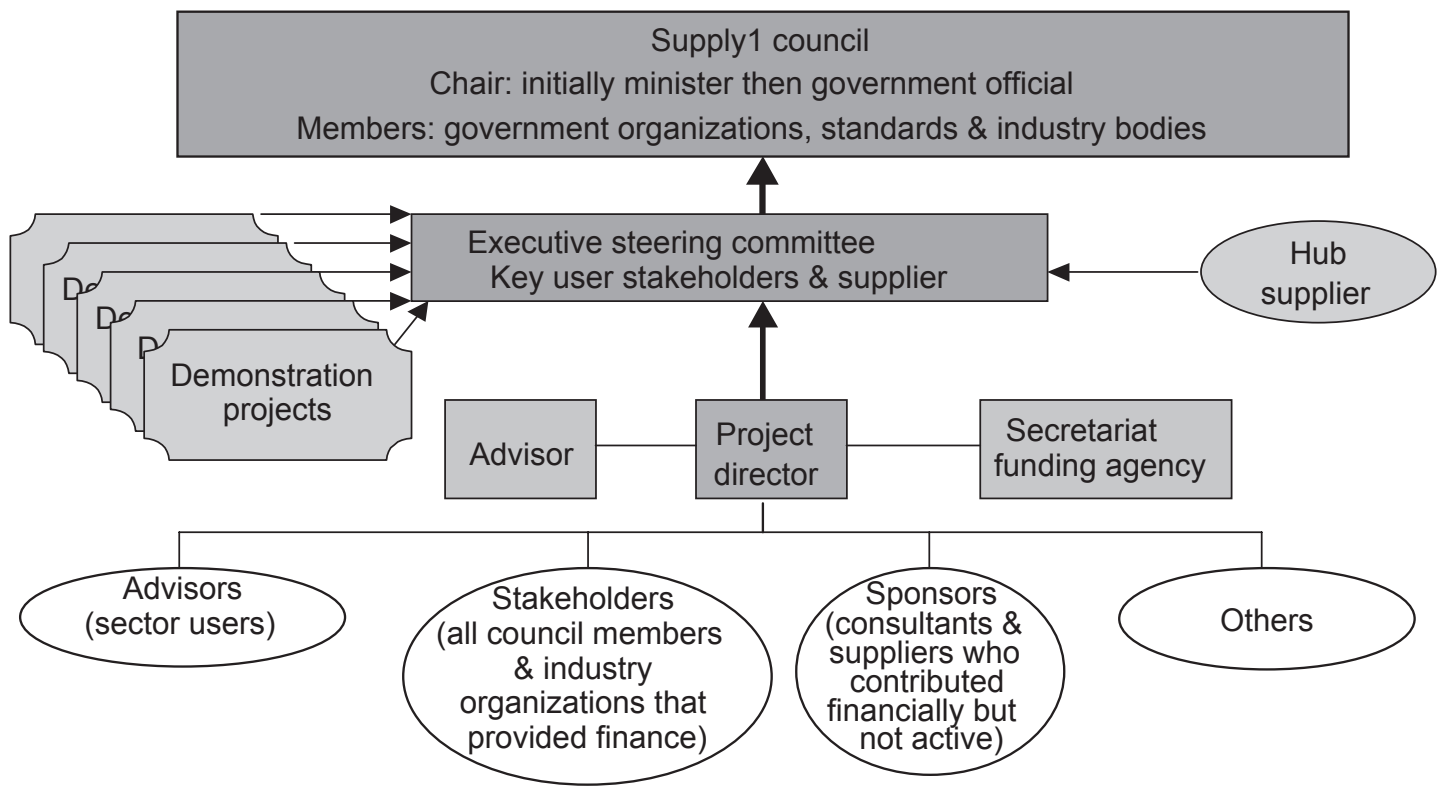

Figure 4. Governance structure for Supply1 stage 1.

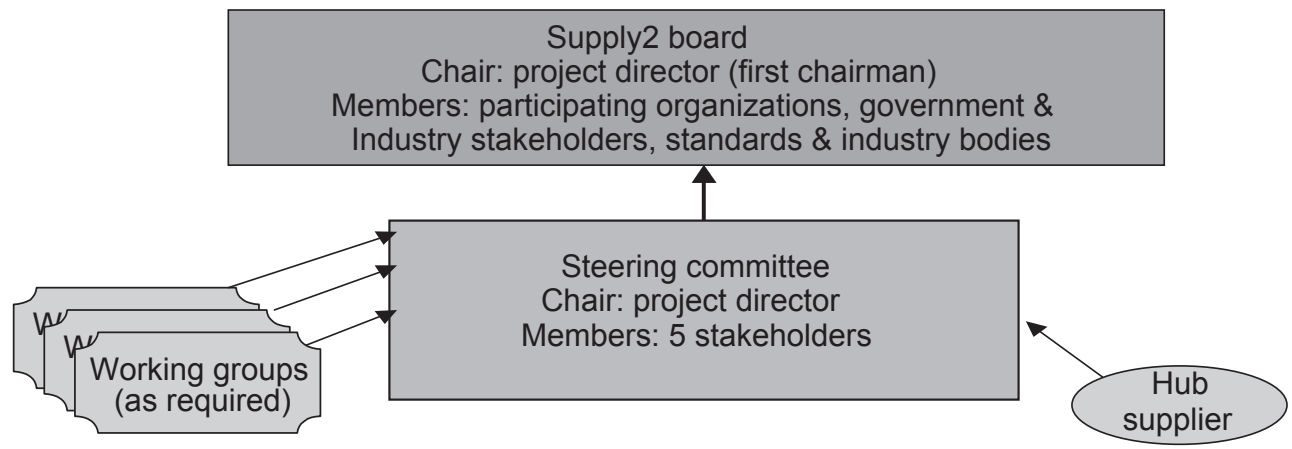

Figure 5. Governance structure for Supply2 stage 1.

The Supply3 governance structure is shown in Figure 6. As in Supply2, the Project Director was appointed as facilitator. Standards for data exchange were agreed. A standards body that was also a member of the Steering Committee was the repository supplier. A project management methodology was not used. The project was coordinated via meetings and well documented minutes. The project had a clearly specified goal that was fully supported by the participating industry organizations.

The Trans governance structure (see Figure 7) shows the differentiated roles of Program Director and Program Manager. The Program Director was responsible for oversighting project development, industry liaison and marketing, and coordinating industry standards development. The Program Manager was accountable for managing the virtual Project Teams comprising representatives from four different states, and for achieving project objectives. Business Teams developed business rules; Technical Teams established architecture and developed ebusiness infrastructure; Rollout Working Groups then tested messages, protocols and infrastructure. Representatives coordinated project activities within their own organization.

An industry-based approach was adopted for developing and reviewing standards. Extensive consultation ensured agreement from industry as a whole, as well as from organizations participating in the project. The Participants' Forum, which met on an ad hoc basis, was established to facilitate communication about progress and to allow participating organizations to be involved in key decisions. To avoid the risk of unfair competitive practices and ensure equity, message standards were set by industry experts in the 


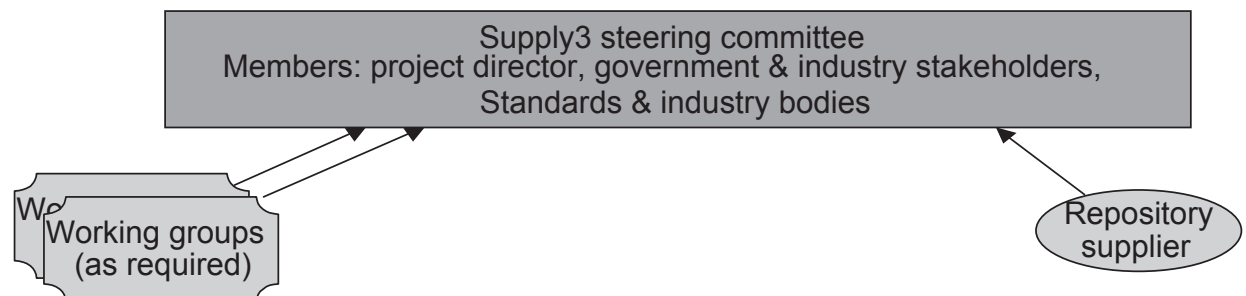

Figure 6. Governance structure for Supply3 stage 1.

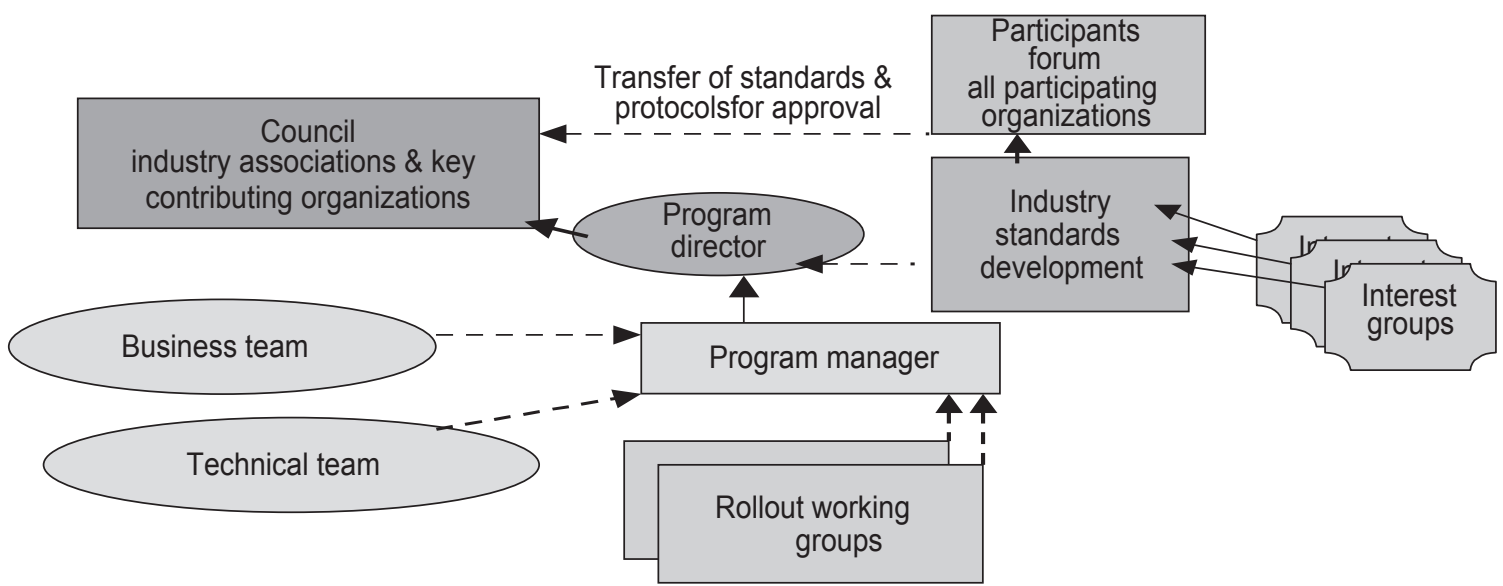

Figure 7. Governance structure for trans stage 1.

Interest Groups, endorsed by the Participants' Forum and approved by the Council. Nevertheless, some members of the Interest Groups were also members of Project Teams. ICT Suppliers were not included in Teams during the Initiative Development Stage to avoid conflict of interest. They were invited to provide information to the Participants' Forum but were not included in the evaluation or decisionmaking processes. This may have slowed the development of products that complied with the messaging standards developed during the project. When a repository was required to facilitate data exchange, after the standards were approved, a tender was issued and a contract negotiated with the supplier.

A comprehensive ICT project management methodology, designed for use within a single authority structure, was modified and adapted by the Trans Program Manager because of its complexity, the volume of documentation and requirement for numerous "sign-offs" on "deliverables" by each participating organization. A detailed project plan was prepared and processes were formally documented. A methodology created to design and develop XML messages was utilised. After testing was completed, the Council formally approved a pilot implementation by four trading partners.
As shown in the DocEx governance structure (see Figure 8) the Project Manager reported to the Project Director but was responsible also to the Quality Manager and the Director of the Lead Consultancy. A central Project Team (equivalent to 3 full-time staff) helped agencies complete project activities This avoided some priority conflicts that occur when representatives are required to continue their assigned activities associated with their organizational role while completing collaborative ebusiness project tasks. The Business Team examined and recommended changes to work processes while the Technical Team recommended standards and implemented infrastructure.

During the Initiative Development Stage of DocEx, which included an initial implementation by three organizations, the ICT project management methodology mandated by government was used as a framework but was supplemented by a collaborative project management methodology. Roles, responsibilities, project plans and schedules were fully documented and approved by the Steering Committee. Teams formally referred recommendations for approval from both the Steering Committee and their own organization. Suppliers attended Technical Team meetings in an advisory capacity. Approvals and other decisions were minuted and action lists were reviewed and followed up at 


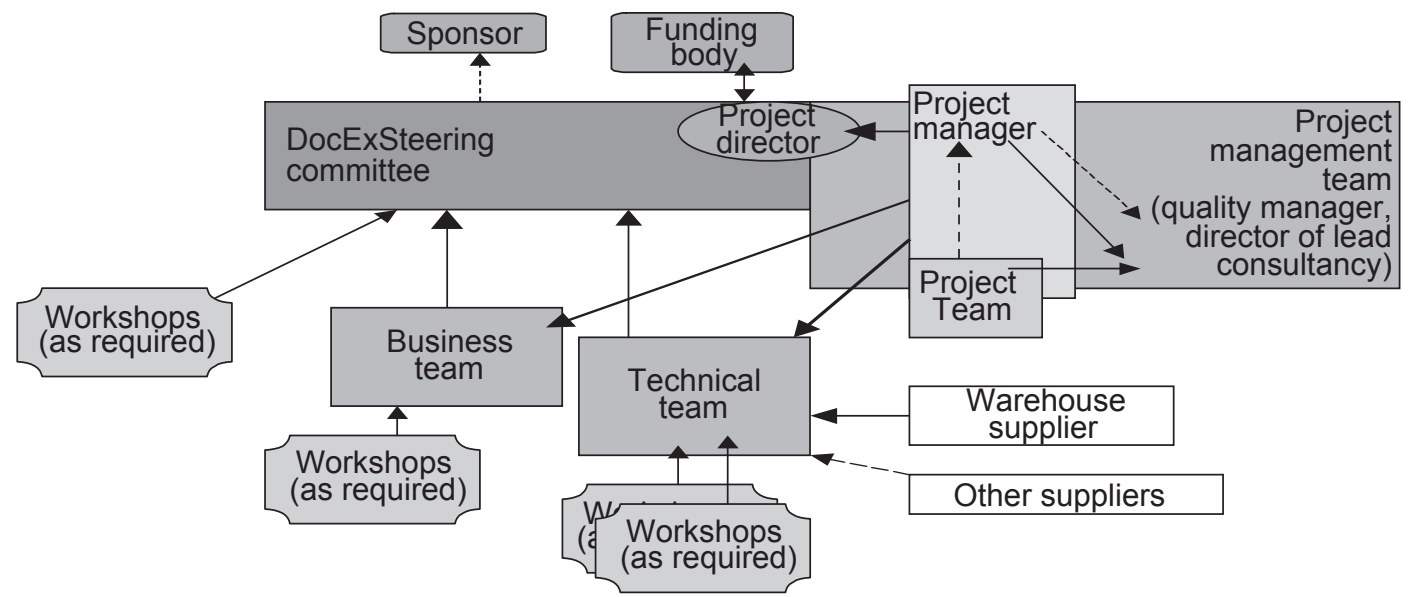

Figure 8. Governance structure for DocEx stage 1.

each meeting. This level of control was appropriate for a project undertaken within the government sector.

\section{Structure, mechanisms and methods for take up and implementation}

The four projects that completed the Initiative Development Stage (Supply1, Supply3, Trans and DocEx) considered the activities that followed as a separate sub-project. As is typical for pilot (or demonstration) projects, industry Take-up and Implementation did not always proceed directly after Stage 1 . The main project that arose from Supply 1 utilised the agreed standards for a common electronic ordering system that allowed internet transactions between wholesalers (that were competitors) and their smaller suppliers. The other demonstration projects from Supply1 were not commercialised or continued. The project structure, similar to that of Supply3 (Figure 6) was headed by a Steering Committee. There was no change in method. The chief executive officers of five organizations agreed to subsidize the system by paying a share of the overhead costs. Strategic autonomy was retained. A separate contract was signed between each participating organization and the hub supplier as the mechanism to commit organizations to implementation. Problems occurred when one large organization introduced a different ICT system and only two organizations implemented the agreed ebusiness solution. Use of the hub ceased due to low usage, and the project ended. Although the project ceased, 16 standards documents for the sector were later published under the chairmanship of the Supply1 Project Director.

After the successful implementation by seven major organizations, the Supply3 governance structure was dissolved and management was handed over to an industry association. It is understood that a standards body provides the repository and users pay membership fees and a fee for each item lodged in the repository.

A report written for discussion prior to the end of the Initiative Development Stage of Trans recommended that a not-for-profit legally constituted company structure be established to facilitate and coordinate industry take up and implementation, maintain and extend the message standards, certify software products from suppliers and exchanges from participating organizations as "compliant" with standards, and resolve disputes. However, it was decided not to formalise the collaboration. Instead, the Council, supported by the industry associations, continued as the governance body. An industry consultant and the Program Director (contracted on a part-time basis) worked to encourage suppliers to expedite release of standards compliant software for use by participating organizations and the industry. No project management methodology was used. A supplier was contracted to provide and manage a repository for product data. A year later, the Trans project was combined with a similar project in a related sector because segments of the electronic messages contained the same data, and some organizations used both types of transaction. A "Charter" was used as the mechanism for establishing the amalgamated project, transferring the ongoing management of the project, the repository contract, and maintenance of the messaging standards. The governance structure was "an unincorporated body" comprising representatives from the industry associations and relevant government regulators. Industry implementation continues as software suppliers provide compliant product and organizations upgrade their systems.

DocEx continued in Stage 2 as an Extended Pilot. Having proven the technology and evaluated the warehouse 
concept, the contract with the warehouse supplier was terminated. To complete the benefits evaluation process, edocuments were exchanged on CD-ROM and loaded onto internal ICT systems for processing by staff. This process continues. Although the DocEx governance structure (shown in Figure 8) was retained, the Steering Committee chairman changed and a new, part-time Project Manager from the Lead Consultancy was appointed. The Quality Manager continued on an ad hoc basis. Project teams met as required. The Steering Committee monitored progress, held workshops to resolve issues and informed staff and other stakeholders about progress. Standard project coordination methods were adopted. The project is ongoing.

\section{Summary and evaluation of the proposal}

The columns in Table 2 summarize key differences in governance structures, mechanisms and methods adopted at the collaboration and project layers by each project over the three stages of the lifecycle.

The descriptions from the case studies confirm that the governance structure used to manage the collaboration and the project changed throughout the lifecycle in response to changes in management function and project activities. The governance structures adopted for collaboration governance reflected the number and nature of participating organizations (e.g. Supply1) and the level of control required (e.g. DocEx). As expected, the project structure, for the Initiative Development Stage of the lifecycle, was determined by the project scope, impact, form of ICT utilised, and number of sub-projects to be completed. The complex, multi-levelled project management structure for Supply1 and Trans reflected the need to coordinate multiple projects with broad scope that included message development, changes to industry practice and process as well as ebusiness ICT. Three models for team structures during the Initiative Development Stage were represented in the five case studies:

1. Independent virtual project teams and working groups coordinated by a governance body (Supply1, Supply2 and Supply3).

2. A combination of virtual project teams within the ebusiness collaborative project (comprising representatives who remained with their own organizations) and separate standards development teams, coordinated by a single governance structure (Trans).

3. Joint teams (comprising representatives from each participating organization, remaining within their organization but assigned to work part-time on the project) and a central Project Team (staffed by contracted expertise), coordinated by governance body supported internal project teams established within each participating organization (DocEx).

In most collaborative ebusiness projects, some participating organizations do not establish internal projects. If the collaborative project structure was mirrored within the organizational structure of each participant, as in DocEx, coordination was facilitated. Once the Initiative Development Stage was completed, project teams were often disbanded and governance structures simplified.

Methods of coordination changed as functions changed. Initiators consulted widely during the Collaboration Formation Stage. Participating organizations needed to agree objectives, budgets and a broad schedule. Trans used a Planning Workshop to assess benefits and refine objectives, Supply1 used interviews to ascertain support, but only DocEx followed a method - government guidelines. These methods were effective because they led to the establishment of the collaboration. During the Initiative Development Stage, when relationships were more established, participating organizations and project activities were coordinated via meetings, which included teleconferencing, held in different locations to facilitate "attendance" by geographically dispersed representatives. A project management methodology was not used in the Supply projects to coordinate activities. Instead, meetings and actions were well documented and circulated. These methods were included in the Trans and DocEx projects where methodologies were used during Initiative Development Stage. When formal project management methodologies were used, management methods were simplified after the Initiative Development Stage was completed. To encourage industry take-up the methods used at the collaboration layer mirrored those used during the Collaboration Formation Stage.

There was no evidence from these case studies that the mechanisms changed due to the lifecycle. A form of written agreement, ranging from a letter to a "signed-off" business case was used as the mechanism to commit participating organizations to projects that were at least partially funded by government. Funding application requirements may have mandated this formality. Contracts were used throughout the lifecycle when suppliers of goods and services (including project management) were engaged. It can be argued that legal mechanisms are appropriate when "deliverables" can be specified and/or measured. This may explain why contracts were used for the supply of consultancy, management, technical services and products but were not used within the collaborative project to commit participating organizations to specific actions. 
Table 2. Summary governance structure, mechanisms and methods.

\begin{tabular}{|c|c|c|c|c|c|c|c|}
\hline \multirow{3}{*}{$\begin{array}{l}\text { Layer } \\
\text { Lifecycle } \\
\text { Project }\end{array}$} & \multirow{2}{*}{\multicolumn{3}{|c|}{$\begin{array}{l}\text { Collaboration layer } \\
\text { Collaboration formation }\end{array}$}} & \multicolumn{4}{|l|}{ Project layer } \\
\hline & & & & \multicolumn{2}{|c|}{ Initiative development } & \multicolumn{2}{|c|}{ Implementation or next stage } \\
\hline & $\begin{array}{l}\text { Collab. } \\
\text { structure }\end{array}$ & $\begin{array}{l}\text { Collab. } \\
\text { mechanism }\end{array}$ & $\begin{array}{l}\text { Collab. } \\
\text { method }\end{array}$ & $\begin{array}{l}\text { Project } \\
\text { structure }\end{array}$ & $\begin{array}{l}\text { Project Mgt } \\
\text { method }\end{array}$ & $\begin{array}{l}\text { Project } \\
\text { structure }\end{array}$ & $\begin{array}{l}\text { Mechanism \& } \\
\text { method }\end{array}$ \\
\hline Supply1 & $\begin{array}{l}\text { Council- } \\
\text { minister \& govt } \\
\text { depts industry } \\
\text { associations, } \\
\text { standards } \\
\text { bodies, key } \\
\text { stakeholders }\end{array}$ & $\begin{array}{l}\text { "Teaming } \\
\text { agreements" } \\
\text { Funding } \\
\text { application. } \\
\text { Contracts with } \\
\text { suppliers. }\end{array}$ & $\begin{array}{l}\text { Meetings. } \\
\text { Consultation. }\end{array}$ & $\begin{array}{l}\text { Exec. steering } \\
\text { committee. } \\
\text { Project director. } \\
\text { Secretariat. } \\
\text { Demonstration } \\
\text { projects \& } \\
\text { working groups, } \\
\text { Advisor, } \\
\text { stakeholder \& } \\
\text { sponsor teams }\end{array}$ & $\begin{array}{l}\text { Written } \\
\text { objectives. } \\
\text { Meetings \& } \\
\text { reports. } \\
\text { Minutes \& other } \\
\text { documentation. }\end{array}$ & $\begin{array}{l}\text { Project steering } \\
\text { committee only. }\end{array}$ & $\begin{array}{l}\text { Separate } \\
\text { contract with } \\
\text { hub supplier. } \\
\text { No project } \\
\text { management } \\
\text { methodology. } \\
\text { Coordination } \\
\text { via meetings. }\end{array}$ \\
\hline Supply2 & $\begin{array}{l}\text { Board - project } \\
\text { director \& } \\
\text { stakeholders }\end{array}$ & $\begin{array}{l}\text { Written } \\
\text { Agreement. } \\
\text { Funding } \\
\text { application. }\end{array}$ & $\begin{array}{l}\text { Meetings. } \\
\text { Consultation. }\end{array}$ & $\begin{array}{l}\text { Steering } \\
\text { committee } \\
\text { Working groups. }\end{array}$ & $\begin{array}{l}\text { Written } \\
\text { objectives. } \\
\text { Meetings \& } \\
\text { reports. } \\
\text { Minutes \& other } \\
\text { documentation. }\end{array}$ & Not applicable. & $\begin{array}{l}\text { Not } \\
\text { applicable. }\end{array}$ \\
\hline Supply3 & $\begin{array}{l}\text { Steering } \\
\text { committee } \\
\text { - stakeholders, } \\
\text { industry, govt \& } \\
\text { standards bodies }\end{array}$ & $\begin{array}{l}\text { Written } \\
\text { agreement. } \\
\text { Funding } \\
\text { application. } \\
\text { s }\end{array}$ & $\begin{array}{l}\text { Meetings. } \\
\text { Consultation. }\end{array}$ & Working groups & $\begin{array}{l}\text { Written } \\
\text { objectives. } \\
\text { Meetings \& } \\
\text { reports. } \\
\text { Minutes \& other } \\
\text { documentation. }\end{array}$ & $\begin{array}{l}\text { Project steering } \\
\text { committee led } \\
\text { by industry } \\
\text { association. } \\
\text { Standards body } \\
\text { as repository } \\
\text { supplier. }\end{array}$ & $\begin{array}{l}\text { Supplier } \\
\text { contract. } \\
\text { No project } \\
\text { management } \\
\text { methodology. } \\
\text { Coordination } \\
\text { via meetings. }\end{array}$ \\
\hline Trans & $\begin{array}{l}\text { Council } \\
\text { - industry } \\
\text { associations, } \\
\text { key contributing } \\
\text { organizations. }\end{array}$ & $\begin{array}{l}\text { Letter of } \\
\text { commitment } \\
\text { renewed } \\
\text { annually } \\
\text { Funding } \\
\text { application } \\
\text { Contracts with } \\
\text { service suppliers }\end{array}$ & $\begin{array}{l}\text { Meetings } \\
\text { Consultation } \\
\text { Planning } \\
\text { Workshop }\end{array}$ & $\begin{array}{l}\text { Program director } \\
\text { \& manager } \\
\text { Project teams } \\
\text { Participants' } \\
\text { forum. } \\
\text { Standards } \\
\text { interest groups }\end{array}$ & $\begin{array}{l}\text { ICT project } \\
\text { management } \\
\text { methodology } \\
\text { modified for } \\
\text { collaborative } \\
\text { project. XML } \\
\text { development } \\
\text { methodology }\end{array}$ & $\begin{array}{l}\text { Council led } \\
\text { by industry } \\
\text { associations \& } \\
\text { key orgs. } \\
\text { Council later } \\
\text { combined with } \\
\text { project in same } \\
\text { sector. }\end{array}$ & $\begin{array}{l}\text { Supplier } \\
\text { contract. } \\
\text { No project } \\
\text { management } \\
\text { methodology. } \\
\text { Coordination } \\
\text { via meetings. }\end{array}$ \\
\hline DocEx & $\begin{array}{l}\text { Steering } \\
\text { committee } \\
\text { - participating } \\
\text { government } \\
\text { organizations }\end{array}$ & $\begin{array}{l}\text { Business case. } \\
\text { Contracts with } \\
\text { suppliers }\end{array}$ & $\begin{array}{l}\text { Meetings. } \\
\text { Consultation } \\
\text { collaboration. } \\
\text { Guidelines. }\end{array}$ & $\begin{array}{l}\text { Project teams. } \\
\text { Workshops. } \\
\text { Internal project } \\
\text { teams within } \\
\text { participating } \\
\text { organizations. }\end{array}$ & $\begin{array}{l}\text { ICT project } \\
\text { management \& } \\
\text { collaborative } \\
\text { project methods }\end{array}$ & $\begin{array}{l}\text { Steering } \\
\text { committee } \\
\text { teams \& } \\
\text { workshops as } \\
\text { required. }\end{array}$ & $\begin{array}{l}\text { Business Case. } \\
\text { Minimal } \\
\text { project } \\
\text { management } \\
\text { methodology. }\end{array}$ \\
\hline
\end{tabular}




\section{Evaluation from practitioner experience}

As in other ICT projects, collaborative ebusiness project management aimed to complete activities in accordance with agreed standards and schedules to achieve project objectives. There were differences among the five projects in the effectiveness of executing this function. Practitioners reported that project objectives for Stage 1 were met by all projects and that, with the exception of Supply2, the outcomes for Stage 2 were "largely met", or "satisfactory", or the project was ongoing. All seven organizations collaborating in Supply3 successfully completed the project. Differences among structure, mechanisms and methods adopted by the five projects were evaluated according to the perceived impact on the project management reported by the practitioners interviewed.

Practitioners noted differences between collaboration management and project management and all agreed "governance [of the participating organizations] was very important" (Interviews 2004-5). They also recognized the importance of managing the three levels. "It seems to me that [teams] are fine and if you have them, you need to manage them properly. There was a willingness of the volunteers as one aspect, and then the good management of them was the other" (Interview 2004). Representatives, and their full support, were crucial to outcome. "The ability of these people to act as a community gratified me" (Interview 2004). Representatives with their own agenda, who did not agree with the project objectives or how they were being implemented, could create problems. "Because I could not stay on things five days a week and because they knew the industry better than I did, I would go to meetings and find that something happened that I was not aware of " (Interview 2004). All practitioners noted that interorganizational project management was very challenging. "I believed instinctively that what I was charged to do could not happen unless I got the CEOs to say yes [but]...what [CEOs] said did not always go down the organization" (Interview 2004). The added management functions arising from "virtuality" were recognised. "Minutes of every meeting show that the project manager had problems ensuring that the members adhered to agreements made at former meetings" (Interview 2005).

\section{Collaboration management}

As described in Section 4, Supply1 and Trans used a multilayered structure to ensure all stakeholders were involved appropriately. All collaborative ebusiness project were headed by a single governance body ("Board", "Council", "Steering Committee") with functions that included setting strategy, policy and objectives, reporting to stakeholders, oversighting project management, contracting for supply of goods and services, resolving disputes and coordinating participating organizations. "I think that the only problem we had was that we needed to cut down the number of the people that wanted to participate" (Interview 2004). The project was "enabled through committees and sponsors who were able to listen, contribute and be interested in how to make all this happen" (Interview 2004). The number of separate projects established by the collaboration and the degree of "virtuality" complicated coordination. One project review of Supply1 expressed concern about coherency and integration across the projects (Report to Government). The Trans project was considered "well coordinated because it was set up as a project early on. It was structured with a project manager, business sponsors and also with top level support from industry organizations" (Interview 2004).

The methods used to determine membership of the governance body affected perceptions of equity. In some projects, the amount of financial contribution from participating organizations was used to establish rights to membership and participation in key decisions. Practitioners were concerned about how "interest groups" impacted on relationships with other organizations and the viability of the collaboration. "The initial relationship depended on 8-9 people who knew each other or it would not have been created. They formed almost a club" (Interview 2004). Industry associations were normally involved in industry wide projects and acted as sponsor(s) and/or chaired the governance body. Practitioners confirmed other research that found industry associations acted as "honest" brokers (Gregor and Menzies, 2000).

Two practitioners queried the effectiveness of using nonlegally binding mechanisms to commit participating organizations to support and provide resources to the project. One practitioner described some participating organizations as "passengers" (Interview 2004). This referred to organizations that joined to learn about ebusiness but were not prepared to commit resources other than the "joining fee". When asked how management could have been improved, one practitioner responded: "The only thing I would do differently if starting again would be to get stronger contracts [with participating organizations] up front" (Interview 2004). Despite the use of contracts, product supplier relationship management was challenging. The supplier role became ambiguous if they were included in the collaboration and the development of standards and also sought to supply ICT products and services. "[The supplier] wanted to be part of the knowledge base and the solution" (Interview 2005). The request for multi-party contracts created problems. A collective contract was refused because "they wanted 11 separate contracts" (Interview 2004). 
Collaboration governance is a combination of formal "rules" (based on measurement and sanctions) and informal control (based on socialisation and norms) that together have an affect on outcome. (Gray and Wood, 1991a, 1991b) The rules, implicit in the methods and procedures used by the governance bodies to run meetings and make decisions, affected the power and influence of participating organizations. For example, some bodies adopted consensus decision-making; others used voting to resolve contentious matters. Some "rules" and procedures were documented in the Trans project to increase transparency. Because of the nature of collaboration among volunteer organizations, decision-making authority was dispersed. Decisions made within the governance body had to be ratified separately within each participating organization. Informal norms established by the members of the governance body were extremely important. The values (e.g. win-win approach) of organizations and their representatives impacted on the social processes and behaviour. Relationships evolved "punctuated by a series of commitments, steps, and 'bargains' explicitly negotiated or implicated, accepted over time" (Report to Government).

\section{Project management}

The five case studies show variations in the management structure. The Supply projects appointed a single Project Director. Trans and DocEx appointed both a Director to coordinate the collaboration manage relationships and liaise with stakeholders, and a Manager to facilitate the project activities. Project Managers often reported to, and were accountable to, several "authorities" with different agendas (e.g. Director, Sponsor). Multiple reporting structures (as in DocEx) added complexity for the Project Manager. The Project Manager needed to be perceived as "neutral" and avoid conflict of interest. "There was a need for me to assure them that I would work with them all without fear or favour" (Interview 2004).

The case studies reflected a variety of project management methods. Trans utilised a modified "traditional" ICT project methodology. The effectiveness of the techniques and processes embodied within methodologies was limited by virtual nature of teams. "The flaw was the difficulty in finding the person in the participating organization who would take ownership of the documents." "In some organizations it was hard to find a person who even wanted to read them because they didn't know how this impacted on 'how we run a business'" (Interviews 2004). Different project management methods prescribed for use within each participant needed to be interfaced with those used for managing the collaborative project. The Supply projects relied more on communication, reporting to the Steering
Committee and peer pressure. "The project manager not only wrote down decisions but sent out minutes to all members for ratification within 2 days of the meeting" (Interview 2004). "We had very strictly controlled minutes and the most important part of those minutes was the audit trail" (Interview 2005). Because the Project Manager lacked formal authority, negotiation, consultation, communication was important.

The use of management methods appropriate to collaborative projects appeared to facilitate achievement of project schedules. Tight coordination in Stage 1 of DocEx and Trans meant that schedules were achieved successfully. An additional reason for the success of Trans in achieving the project schedule was considered to be "probably the good management of the volunteers who were in the [teams]" (Interview 2004). Although the outcomes and objectives were achieved, there were "significant" delays for Supply1 and Supply3 where no project management methodology was adopted. "It went over time not because we were late doing things but because more and more things kept coming up" (Interview 2005). The scope and nature of Supply1 affected schedules. "We had a schedule for the delivery of standards but we caused the delay deliberately... We needed to consider the needs of small organizations in the sector" (Interview 2004). Complex structures for project teams undertaking different tasks (e.g. technical versus business) meant decisions were subject to separate review to assess their compatibility and consistency before they were referred to the governing body. The need for representatives to have project decisions ratified by their own organizations affected the timeliness of completing project activities, often severely. "You would rush to complete an activity and we would all agree something and they would all need to get back to me by an agreed date but that didn't happen for clerical or other various reasons" (Interview 2004). It is suggested that the use of an appropriate project management methodology may have reduced delays in meeting project schedules. The documentation required by methodologies (e.g. detailed specifications) made available in advance of activities may have added credibility and enabled internal resources to be better prioritised. The transparency inherent in the processes used with project management methodologies may have focussed representatives on achieving project objectives.

\section{Conclusions}

As illustrated in Table 3, this research confirmed that the attributes of collaborative ebusiness projects affected the appropriateness of governance structure, mechanism and methods. The challenges of managing the three levels of participating organizations, virtual teams and representatives and their interactions and inter-relationships 
Table 3. Suggested governance structure, mechanisms and methods appropriate to attributes.

\begin{tabular}{ll}
\hline Attribute & Structure \\
Three levels to manage: & Coordinate participating \\
organizations, teams & organizations at the \\
\& representatives plus & collaboration layer via a \\
their interactions & governance body with clearly \\
& defined \& documented \\
& objectives \& functions. \\
& Ensure management roles \& \\
& reporting accountabilities are \\
& defined \& documented. \\
& Establish project teams with \\
& clear documented functions. \\
& Establish project teams for \\
& the collaborative ebusiness \\
& project in each participating \\
& organization. \\
& Ensure participating \\
organizations are represented. & Ensure project objectives are \\
agreed \& shared. & \\
Voluntary collaboration &
\end{tabular}

Virtuality

$$
\begin{aligned}
& \text { Establish project teams } \\
& \text { for collaborative ebusiness } \\
& \text { project within participating } \\
& \text { organizations. }
\end{aligned}
$$

Level of control required Adopt a multi-layered structure (e.g. due to risk) with formalized reporting to reduce perceived risk in competitive environments.
Three stage lifecycle Change structure over lifecycle to reflect management functions.

Number of participating Adopt a multi-layered structure organizations \& stakeholders to increase opportunity for involvement by participating organizations and other stakeholders.

Scope \& reach of technology
Mechanism

Methods

Obtain written commitment Ensure methods are appropriate for appropriate for project funding and resourcing requirements. Use contracts for supply of services \& products.

Document objectives \& agreements.

Use contracts for supply of services \& products.

Ensure mechanisms reflect level of risk \& commercial certainty. the context \& include coordination of organizations, teams \& representatives. Adopt collaborative project management methods. Establish clear goals for project and teams. Ensure all decisions are agreed. Document meetings to increase transparency. Consult \& communicate widely.

Ensure meaningful communication \& consultation.

Agree project objectives \& plans. Agree project management methods. Negotiate with key participating organizations \& stakeholders about risks \& benefits. Ensure communication among dispersed representatives.

Rotate meeting locations.

Allow extra time for dispersed decisionmaking.

Document processes \& rules to increase transparency.

Adopt appropriate management Document obligations, rights methodology.

\& sanctions to strengthen Document, circulate and confirm control.

decisions.

Change methods over lifecycle to reflect activities and functions.

Add management functions \& activities to establish \& maintain collaboration \& implement initiative.

Allow increased time for decision-making when the number of participating organizations is large \& /or the structure is multi-layered.

Agree methods to coordinate activities \& report progress.

Negotiate equity for diverse participating organizations \& stakeholders.

Use contracts for supply of good \& services, including expertise.
Adopt development methods appropriate to the technology.

Utilize expertise to develop standards \& technology. 
were increased by the voluntary nature of the collaboration and by virtuality. The case studies show that both the collaboration and the project layers of collaborative projects must be managed effectively if stated outcomes are to be achieved. Collaboration adds extra stages to a project lifecycle to allow for formation of a type of virtual organization and for an ebusiness initiative to be taken up and implemented throughout a trading chain. The nature of the trading, value or transaction chain (e.g. level of competition among participating organizations, commercial and strategic sensitivity) may increase the perceived risk of collaboration. The level of control may be determined by risk or by factors associated with funding requirements or the nature of organizational roles and environments (e.g. need to account for public money).

Table 3 aims to help practitioners evaluate the appropriateness of governance structure, mechanisms and methods (Columns 2-4) according to the attributes (listed in Column 1) of a specific collaborative ebusiness project. Suggestions for appropriate structures, mechanisms and methods for each attribute identified from this research are shown in the rows. For example, the governance structure can be expanded at the collaboration layer to allow for large numbers of participating organizations to be represented and at the project layer to include representatives with the diverse skills required by complex technology. Appropriate management methods appear to provide transparency and focus organizational, representative and team efforts on activities for achieving agreed objectives within specified timeframes. Although further research is required, it appears that management processes incorporated within a methodology designed for managing the virtual organization and virtual teams involved in collaborative projects may improve outcomes.

This research found the proposition postulated in this paper was partially proven. The governance structures and methods used to manage the collaboration and the project changed throughout the three stages of the "Collaborative Project Management Lifecycle ${ }^{\circledR \circledast}{ }^{\circledR}$ to support differing management functions and activities. However, the findings did not support the proposition that mechanisms also change. Rather than changing with the lifecycle, the mechanisms adopted related to the need for commercial clarity and control.

This paper contributes to practice by recognising the three levels of analysis (participating organizations, virtual teams and representatives) and utilizing the three stages of the "Collaborative Project Management Lifecycle" ${ }^{\circledR \circledast}$ to examine the implications of governance structures, mechanisms and methods from a management perspective. The comparison of case study findings with practitioner experience, provides information to assist management to select options for governance structure, mechanisms and methods appropriate to the attributes of specific collaborative ebusiness projects. Because collaborative ebusiness projects may be considered as a form of virtual organization, the findings may be applicable to practitioners managing other forms of collaboration in the "virtual world". These findings may also apply to projects involving technology other than ebusiness. Although aimed at practitioners, the paper contributes to research by synthesizing and building on findings related to collaborations, project management, virtual organizations and virtual teams and applying these to a real world environment. There is growing recognition by ebusiness researchers of the importance of considering multiple levels of analysis in order to explain the interactions, complexity and outcomes of ebusiness collaboration. This examination of the impact of structure, mechanisms and methods used to coordinate the collaboration and project management layers of the ebusiness collaborative project contributes to research on project management in virtual environments.

\section{Acknowledgements}

The author appreciates and acknowledges the significant contribution of the eight practitioners interviewed for this research. This paper would not have been possible without their willingness to share their experience and expertise. The author acknowledges the contribution of the two anonymous reviewers in improving the focus of this paper. She especially thanks Dr Bernard Katzy for his insightful comments. The author would also like to thank her PhD supervisor Dr Ross Jeffery for his comments and support.

\section{References}

Allen, D., D. Colligan, A. Finnie and T. Kern, 2000. Trust, Power and Interorganizational Information Systems: The Case of the Electronic Trading Community Translease. Information Systems Journal, Vol. 10, pp. 21-40.

Anjum, M., M.I. Zafar and S.A. Mehdi, 2006. Establishing Guidelines for Management of Virtual Teams. Retrieved 30 March, 2006, from www.ejov.org

Bain, P.G., L. Mann and A. Pirola-Merlo, 2001. The Innovation Imperative: The Relationships Between Team Climate, Innovation, and Performance in Research and Development Teams. Small Group Research, Vol. 32 (No. 1), pp. 51-73.

Bloor, M., 1997. Techniques of Validation in Qualitative Research: a Critical Commentary. In Miller, G. and R. Dingwall (Eds.), Context and Method in Qualitative Research. London: Sage Publishers Ltd. 
Cameron, J., 2002. UN-EDIFACT or XML: A Critical eCommerce Decision. Paper presented at the 10th Polish EDI- eCommerce Conference: "Wybrane Problemy Zastosowania Electronic Data Interchange-Electronic Commerce", (M. Niedzwiedzinkkiegos.), Lodz University, Lodz, Poland.

Cameron, J., 2005. Ten Concepts for an eBusiness Collaborative Project Management Framework. Paper presented at the 18th Bled eConference: "eIntegration in Action", (D. Vogel, P. Walden, J. Gricar and G. Lenarts.), Faculty of Organisational Sciences, University of Maribor, Bled, Slovenia.

Cameron, J., 2006. The eBusiness Collaborative Project Lifecycle. Paper presented at the 15th International Conference on Management of Technology: "East Meets West: Challenges and Opportunities in the Era of Globalization", (G. Wu and M. von Zedtwitzs.), International Association for Management of Technology, Beijing, China.

Cameron, J. and R. Clarke, 1996. Towards a Theoretical Framework for Collaborative Electronic Commerce Projects Involving Small and Medium-Sized Enterprises. Paper presented at the 9th International Conference on EDI-IOS: "Electronic Commerce for Trade Efficiency and Effectiveness", (P. Swatman, J. Gricar and J. Novaks.), Moderna Organizacija, Kranj, Bled, Slovenia.

Clarke, R., 1994a. EDI in Australian International Trade and Transport. Paper presented at the 7th International EDI-IOS Conference: "Electronic Commerce - Electronic Partnership", (J. Gricar and J. Novaks.), University of Maribor, Bled, Slovenia.

Clarke, R., 1994b. Report on EDI Implementation in the Transport Sector: An Assessment Stocktake. Canberra: National Consultative Group on Transport EDI.

Creswell, J.W., 2003. Research Design: Qualitative, Quantitative and Mixed Methods Approaches (2nd Edition ed.). Thousand Oaks, California: Sage Publications Inc.

Crowston, K. and B. Scozzi, 2002. Open Software Projects as Virtual Organizations: Competence Rallying for Software Development. IEE Procedings on Software, Vol. 149 (No. 1), pp. 3-17.

Emmelhainz, M., 1990. Electronic Data Interchange: A Total Management Guide. New York: Van Nortrand Reinhold.

Fear, H. and P. Barnett, 2003. Holding Fast: The Experience of Collaboration in a Competitive Environment. Health Promotion International, Vol. 18 (No. 1), pp. 5.14.

Gallivan, M. and G. Depledge, 2003. Trust, Control and the Role of Interorganizational Systems in Electronic Partnerships. Information Systems Journal, Vol. 13, pp. 159-190.

Grabowski, M. and K. Roberts, 1999. Risk Mitigation in Virtual Organizations. Organization Science, Vol. 10 (No. 6), pp. 704721.

Gray, B. and D. Wood, 1991a. Collaboration Alliances: Moving from Practice to Theory - Towards a Comprehensive Theory of Collaboration. Journal of Applied Behavioural Science, Vol. 27 (No. 2), pp. 146-160.
Gray, B. and D. Wood, 1991b. Collaborative Alliances: Moving from Practice to Theory - Preconditions, Process and Outcomes. Journal of Applied Behavioural Science, Vol. 27 (No. 1), pp. 3-16.

Gregor, S. and D. Menzies, 2000. The Role of the 'Honest Broker' in the Development of Interorganizational Systems: A Case Study in the Beef Industry. Paper presented at the 13th Bled Electronic Commerce Conference: "The End of the Beginning", (S. Klein, O'Keefe, B., Gricar, J., Podlogar, M.s.), Moderna Organizacija, Kranj, Bled, Slovenia.

Grevins, J.. 2002. Project Virtuality Effects on Project Team Processes and Project Success. Unpublished PhD, State University of New York, Buffalo.

Hardy, C., T.B. Lawrence and D. Grant, 2005. Discourse and Colloboration: The Role of Conversations and Collective Identity. Academy of Management Review, Vol. 30 (No. 1), pp. 58-77.

Hartono, E. and C. Holsapple, 2004. Theoretical Foundations for Collaborative Commerce Research and Practice. Information Systems and eBusiness Management, No. 2, pp. 1-30.

Hirst, J. and A. Robertson, 1997. The Tradegate Australia Initiative: An Example of a Co-operative Approach to Electronic Commerce. Sydney: Tradegate Australia Ltd.

Jardim-Goncalves, R., J. Cha and A. Steiger-Garcao, 2003. 10th ISPE International Conference on Concurrent Engineering: "Enhanced Interoperable Systems". Paper presented at the Proceedings of the 10th ISPE International Conference on Concurrent Engineering: Enhanced Interoperable Systems, (R. Jardim-Goncalves, J. Cha and A. Steiger-Garcaos.), A.A. Balkema Publishers, Madeira, Portugal.

Katzy, B.R., 1998. Design and Implementation of Virtual Organizations. Paper presented at the IEEE Conference, IEEE.

Kinni, T.B., 1994. Boundary Busting Teamwork. Industry Week, Vol 243 (No. 6), pp. 72-80.

Koch, M., K. Moslein, R. Reichwald and J. Schlinchter, 2004. TiBiD Trust Building and Matchmaking Support for Virtual Enterprises. Paper presented at the 17 th Bled eCommerce Conference: "eGlobal", (Y. Tan, D. Vogel, J. Gricar and G. Lenarts.), Faculty of Organizational Sciences, University of Maribor, Bled, Slovenia.

Leenders, R.T., J.M.L. van Engelen and J. Kratzer, 2003. Virtuality, Communication, and New Product Team Creativity: A Social Network Perspective. Journal of Engineering and Technology Management JET-M, Vol. 20, pp. 69-92.

Loebbecke, C., P. Fenema P. Powell, 1998. Knowledge Transfer Under Coopertition. Paper presented at the IFIP WG8.2 and 8.6 Joint Working Conference on Information Systems: "Current Issues and Future Changes", (T. J. Larsen, L. Levine and J. I. DeGrosss.), IFIP, Helsinki, Finland.

Lu, M., M.B. Watson-Manheim, K.M. Chudoba and E. Wynn, 2006. Virtuality and Team Performance: Understanding the Impact of Variety of Practices. Journal of Global Information Technology Management, Vol. 9 (No. 1), pp. 4-23. 
Lyytinen, K. and J. Damsgaard, 2001. What's Wrong with the Diffusion of Innovation Theory? Paper presented at the IFIP TC8 WG8.6 Working Conference: "Diffusing Software Product and Process Innovations", (M. Ardis and B. Marcolins.), Kluwer Academic Publishers, Banff, Canada.

McGrath, M. and E. More, 2002. Forging and Managing Online Collaboration: the ITOL Experience. Canberra, Australia: National Office for the Information Economy.

McNichols, T. and L. Brennan, 2004. Evaluating eCollaboration: Toward a Positioning Map for Supply Chain Integration. Paper presented at the 17th Bled eCommerce Conference: "eGlobal", (Y. Tan, D. Vogel, J. Gricar and G. Lenarts.), Faculty of Organizational Sciences, University of Maribor, Bled, Slovenia.

mFundEC., 2001-2003. mFundEC Programme. Retrieved 12 December 2003, from www.ifsa.com.au

Miles, R.E., G. Miles and C.C. Snow, 2005. Collaborative Entrepreneurship. Stanford, California: Stanford Business Books.

NOIE, 2002. Guide to Successful eBusiness Collaboration. Retrieved 6 February, 2004, from www.noie.gov.au

Olle, T.W., J. Hagelstein, I.G. MacDonald, C. Rolland, H.G. Sol, F.J.M. Van Aasshce, et al. (Eds.), 1988. Information Systems Methodologies: A Framework for Understanding: AddisonWesley Publishing Company.

OVUM, 2003. Productivity and Organisational Transformation: Optimising Investment in ICT. Retrieved 6 February, 2004, from www.noie.gov.au

Piccoli, G. and A. Powell, 2004. Virtual Teams: Team Control Structure, Work Processes, and Team Effectiveness. Information Technology and People, Vol. 17 (No. 4), pp. 359-379.

Project Management Institute, U.,2000. A Guide to the Project Management Body of Knowledge. Pennsylvania, USA: Project Management Institute.

Rayport, J.E. and B.J. Jaworski, 2001. "e-Commerce". Singapore: McGraw-Hill/Irwin.

Reimers, K., R. Johnson S. Klein, 2004. The Shaping Of Inter-Organisational Information Systems: Main Design Considerations Of An International Comparative Research Project. Paper presented at the 17th Bled eCommerce Conference: "eGlobal", (Y. Tan, D. Vogel, J. Gricar and G. Lenarts.), Faculty of Organizational Science, University of Maribor, Bled, Slovenia.

Rogers, E.M., 1995. Diffusion of Innovations (Fourth Edition ed.). New York: The Free Press.

Royal Academy of Engineering \& British Computer Society (2004): The Challenges of Complex IT Projects (Report). London: The Royal Academy of Engineering \& British Computer Society.

Seddon, P., S. Staples, R. Patnayakuni and M. Bowtell, 1999. Dimensions of Information Systems Success. Communications of the Association for Information Systems., Vol. 2 (Article 20).

Silverman, D., 2000. Doing Qualitative Research. London: Sage Publications Ltd.
Speier, C. and M.G. Harvey, 1998. Virtual Management of Global Marketing Relationships. Journal of World Business, Vol. 33 (No. 3).

Svirskas, A. and B. Roberts, 2003. Towards Business Quality of Service in Virtual Organisations Through Service Level Agreements and ebXML. Paper presented at the 10th ISPE International Conference on Concurrent Engineering: "Enhanced Interoperable Systems", (R. Jardim-Goncalves, J. Cha and A. Steiger-Garcaos.), A.A. Balkema Publishers, Madeira, Portugal. Tradegate. (1994-97). Tradegate Newsletters. Tradegate News.

Tradegate, 2003. Tradegate Projects. Retrieved 12 December, 2003, from www.tradegate.org.au

Tradegate-ECA. (1997-2002). Tradegate ECA Newsletters. ECEdge.

West, M.A., 2002. Sparkling Fountains or Stagnant Ponds: An Integrative Model of Creativity and Innovation Implementation in Work Groups. Applied Psychology: An International Review, Vol. 51 (No. 3), pp. 355-424.

Wilkins, L., P. Swatman and T. Castleman, 2001. AQIS, EXDOC and the 'Meaties': An Interpretivist Case Study of an Australian Export Documentation System Implementation. Paper presented at the 14th Bled Electronic Commerce Conference - "e-Everything: e-Commerce, e-Government, e-Household, e-Democracy", (B. O'Keefe, C. Loebbecke, J. Gricar, A. Pucihar and G. Lenarts.), Bled, Slovenia.

Yin, R., 1994. Case Study Research: Design and Methods (2nd Edition ed.). Thousand Oaks, California: Sage Publications. 